\title{
DIGITAL ELEVATION MODEL ANALYSIS FOR DAM SITE SELECTION USING GIS
}

\author{
Dr. Khalid A. Alkhuzai ${ }^{1}$ and Dr. Nagi Zomrawi Mohammed ${ }^{* 2}$ \\ ${ }^{1}$ Associate Professor, Civil Engineering Department, Faculty of Engineering, Albaha \\ University, (KSA). \\ ${ }^{2}$ Associate Professor of Surveying and Digital Mapping, Faculty of Engineering, Civil \\ Engineering Department, Albaha University (KSA), Sudan University of Science and \\ Technology, Faculty of Engineering (Sudan).
}

*Corresponding Author
Dr. Nagi Zomrawi
Mohammed
Associate Professor of
Surveying and Digital
Mapping, Civil Engineering
Department, Faculty of
Engineering, Albaha
University (KSA), Sudan
University of Science and
Technology, Faculty of
Engineering (Sudan),
orcid.org/0000-0002-1181-
5630

\section{ABSTRACT}

Water security that comprises both availability and quality of water is an important indicator of the health of human life in any area. In addition to drinking, water is important for agriculture, food security, and industry. Water demand increase with population growth and change to modern style life that places new stress on conservation of water resources and gives new challenges to compensate for the high population. ${ }^{[4]}$ The future vision of the ministry of environment, water and agriculture in the Kingdom of Saudi Arabia (KSA) aims to achieve sustainability of the environment and natural resources, in such a manner that would ensure water security, contribute to achieving food security, and improve quality of life in KSA. ${ }^{[10]}$ Geographical Information System (GIS) nowadays becomes an important tool that

supports decision-making in different fields. GIS packages have special tools for spatial analysis and hydrologic modeling. This research work oriented to use Geographical Information System (GIS) in mapping and selection of dam/reservoir site in Albaha Area (KSA) based on analyzing Digital Elevation Model (DEM). The Digital Elevation Model of the study area was used as a base of this study. First, the DEM was enhanced then used to study the flow direction and flow accumulation, delineating watersheds, and creating stream 
networks. The contour map was created to reflect a clear topographic image for the study area. After identifying the most suitable site for locating dam/reservoir, three cases were studied; Higher elevation, Intermediate and Lower elevation. Results showed that the topography of the study area can be utilized to locate a proposed dam at Almikhwah province. This dam can reserve water between about 426 to 9.8 million cubic meters with a dam height of 78 to $5 \mathrm{~m}$ respectively. On the other hand, the proposed dam length may vary from 625 to $247 \mathrm{~m}$. Moreover, GIS tools with DEM reflect powerful, easy, quick, and cheap tools for preliminary dam or reservoir site selection.

KEYWORDS: Digital Elevation Model (DEM), Flow Accumulation, Flow direction, Geographical Information System (GIS), Image enhancement, Pour point, Sink, Stream networks, Watersheds.

\section{INTRODUCTION}

Identifying dam locations in arid and semi-arid areas is a strategic objective. The Kingdom of Saudi Arabia (KSA) occupies about four-fifths of the Arab Peninsula, with a total area of around 2,000,000 square kilometers. It has a diverse topography. The Tihama coastal plain lies along the Red Sea. To the east of this plain, lies a chain of mountains called Sarawat. Several large valleys slope eastward and westward from these mountains. To the east of the chain stands the Najd Plateau which extends eastward. The Empty Quarter in the southeastern part of the Kingdom. The eastern coastal plain consists of large sand areas.

This diverse topography of the kingdom makes the climate varies from one region to another. The Kingdom is generally hot in summer and cold in winter where rains fall often. Moderate climate is seen in the west and the southwestern part of the Kingdom. Dry hot summer and cold winter in the interior parts, and high temperature and humidity in the coastal areas.

Major parts of the Kingdom usually receive scanty amounts of rain in winter and spring. However, in the summer, rainfall is significant in the southwestern mountains. Humidity is high on the western coasts and mountains almost all year. ${ }^{[1]}$

With the absence of natural rivers, water resources can be conserved by construction dams/reservoirs especially in rainy areas. Where choosing a suitable site is a crucial phase in Dam/reservoir construction. 
A dam is an obstruction constructed across a stream or river. At the back of this barrier, water is collected forming a pool. It can be constructed from earth, rocks, steel, or other materials.

Dams can be used to collect water in a lake for drinking, irrigation, or recreation. The energy of this collected water can be used to turn a mill to grind wheat or to turn the blades of a turbine to generate electrical power. Dams can also serve as protection for the residential areas located downstream.

The selection of a site for constructing a dam or reservoir should be governed by many factors including topography, geology and foundation conditions, availability of materials, spillway size and location, earthquake zone, the height of the dam, and other considerations such as the life of dam, the width of roadway to be provided over the dam and overall cost of the construction and maintenance. ${ }^{[9]}$

The application of GIS in dam site selection was studied by several researchers. Rami AlRuzouq and others (2019). ${ }^{[7]}$ used GIS and machine learning approach in suitability mapping. Muhammad Ateeq Qureshi (2015). ${ }^{[6]}$ used remote sensing and GIS in dam/reservoir sites selection.

\section{GIS AND DEM}

Geographical Information System (GIS) is an Information System (IS) for creating, maintaining, managing, and using geographic knowledge. It is an integrated platform for spatial data management and analysis whenever geographical information in digital form is manipulated. ${ }^{[2]}$

It has been evolved in decision support in different disciplines such as engineering, urban planning, geology, agriculture, forestry, security, disaster management, and so on.

A Digital Elevation Model (DEM) is a representation of the topographic surface of the earth that can be created from different sources of data. At the present, remote sensing satellites represent the important source of DEMs for topographic mapping.

Numbers of websites that provide DEMs such as USGS Earth Explorer and ASF data search Vertex. These types of data are normally collected using remote sensing satellites using either Radar or Lidar technology. 
The DEM can be manipulated and analyzed using GIS through different tools such as surface, solar radiation, and hydrologic modeling.

hydrologic modeling has special tools in GIS packages, especially ArcGIS. The hydrologic modeling tools in the ArcGIS Spatial Analyst extension toolbox provide methods for describing the physical components of a surface. ${ }^{[5]}$

The hydrologic tools allow to identify of sinks, determine flow direction, calculate flow accumulation, delineate watersheds, and create stream networks.

\section{STUDY AREA}

Albaha area which represents one of the thirteen geographic regions (Emirates) of the Kingdom of Saudi Arabia (KSA), is located in the southwest part of the kingdom with an area of about $9,921 \mathrm{~km}^{2}$, and a population of 476,172 (2017). The region includes five provinces; Albaha, which is the capital, Baljurashi, Almandaq, Almikhwah, and Alaqeeq. ${ }^{[8]}$

The variation in the topography of Albaha influences the climate of the region. Alsarat area is exposed to the formation of clouds and fog, in the winter. In spring and summer, the climate is mild and pleasant. The Tihama is hot in summer, warm in spring, and mild in winter. The climate in general falls in the arid zone. Relative humidity varies between $52 \%$ and $67 \%$, with maximum temperatures of $23^{\circ} \mathrm{C}\left(73^{\circ} \mathrm{F}\right)$, and minimum temperatures of $12^{\circ} \mathrm{C}\left(54^{\circ} \mathrm{F}\right)$.

The study was carried out in Albaha in the area located between $(719,067.423 \mathrm{~m}$, 2,227,620.879 m) Northwest and $(799,712.584 \mathrm{~m}, 2,156,500.737 \mathrm{~m})$ Southeast UTM projected coordinates.

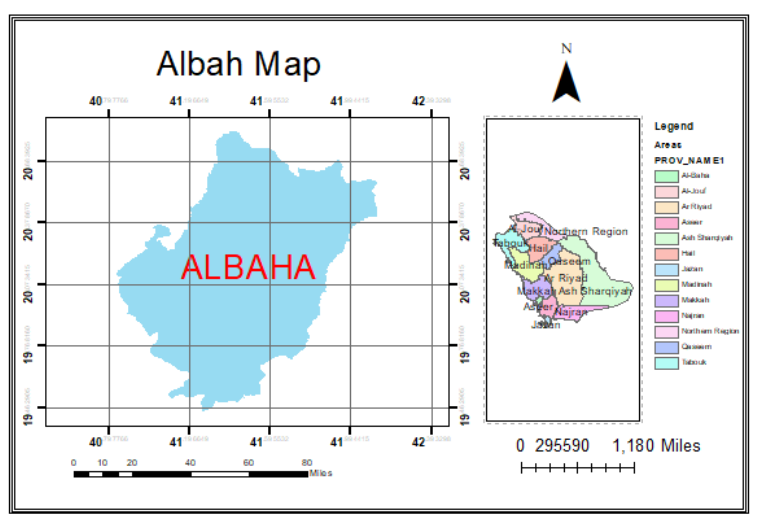

Fig. 1: Location of Albaha area in KSA. 


\section{SOURCE OF DATA}

The topographic surface of the study area was studied through a Digital Elevation Model (DEM). Alaska Satellite Facility (ASF) downlinks, processes, archives, and distributes remote-sensing data to scientific users around the world. Its mission is to make remotesensing data accessible. ASF operates the NASA archive of Synthetic Aperture Radar (SAR) data from a variety of satellites and aircraft.

An ASF 12.5 m high-resolution terrain corrected Digital Elevation Model was obtained as shown in figure (2) below. The DEM was extended between $(719,067.423 \mathrm{~m}, 2,227,620.879$ $\mathrm{m})$ Northwest and $(799,712.584 \mathrm{~m}, 2,156,500.737 \mathrm{~m})$ Southeast UTM projected coordinates that cover most of the mountain parts of Albaha area. Its elevation varies between $40 \mathrm{~m}$ and $2568 \mathrm{~m}$ above mean sea level.

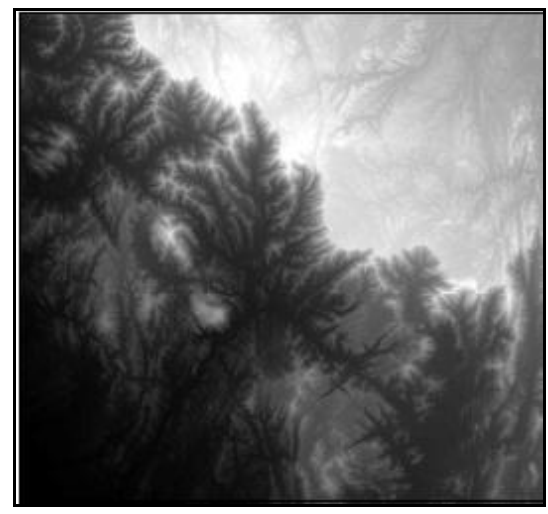

Fig. 2: DEM of the study area.

\section{DATA PROCESSING AND RESULTS}

ArcGIS 10.8 was used to process the DEM of the study area.

In digital data acquisition, some errors such as sinks, and peaks may occur due to the resolution of the data. These errors may make the derived network to be discontinuous. They can be removed by the Fill tool. Fill tool used to locate and fill sinks by iteration until all sinks within the specified height limit are filled.

The DEM of the study area was filled to eliminate all expected discontinuity errors using the ArcGIS Fill command tool.

After eliminating expected sinks and peaks errors, the DEM was used to display flow direction. The flow direction of a network specifies the direction in which commodity flows 
through. ArcGIS stores this information for edge features in a network. Using the utility network analyst toolbar, flow direction can be displayed.

Figure (3) hereunder, represents the direction of flow of the study area.

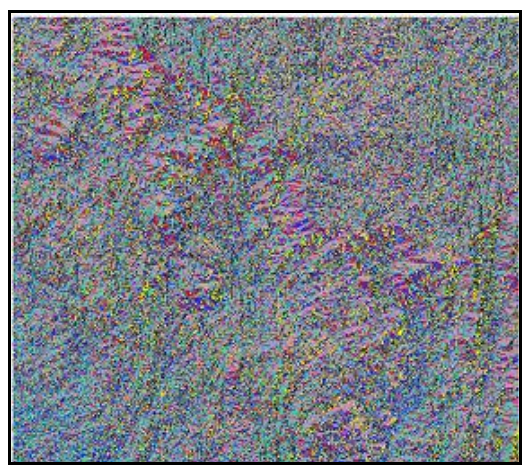

Fig. 3: Flow direction of the study area.

Utilizing the flow direction of the study area, accumulation flow can be derived using the ArcGIS Flow Accumulation tool. It calculates accumulated flow as the accumulated weight of all cells flowing into each downslope cell in the output raster.

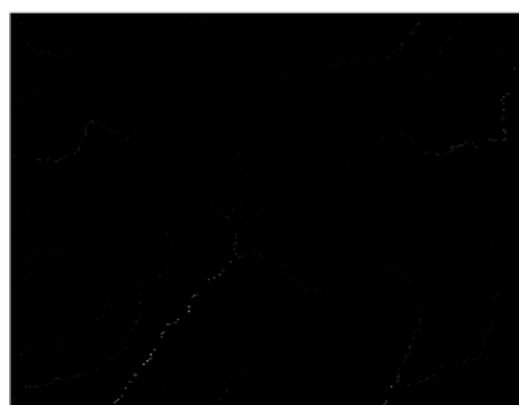

Fig. 4: Flow accumulation result.

To control the output value for each cell based on the conditions placed on the input values, the cell value can be evaluated as true or false. This is done by using the command Con from ArcGIS spatial analyst tool.

The flow accumulation image obtained above was subject to conditional evaluation with expression value greater than 100 and input false raster value or constant value as 1 . The figure below illustrates the result obtained after the conditional evaluation was carried out. 


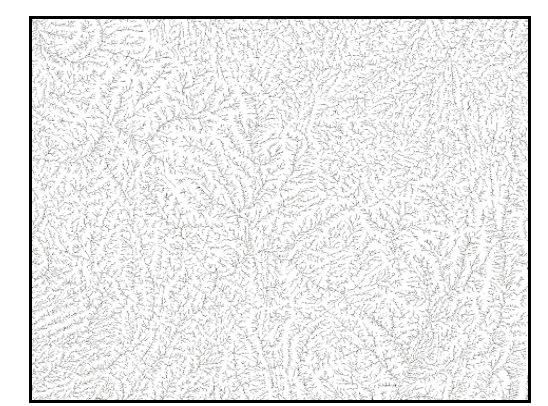

Fig. 5: Conditionally evaluation image.

Stream networks can be ordered numerically to link the number of streams in a stream network. This order identifies and classifies types of streams based on their numbers of tributaries. First-order streams are dominated by the overland flow of water; they have no upstream concentrated flow.

Two approaches in the stream order tool can be used to assign orders. These are the Strahler method and Shreve method. ${ }^{[5]}$

The stream order of the study area was obtained from the enhanced flow accumulation image using the Strahler method as shown in figure (6) below.

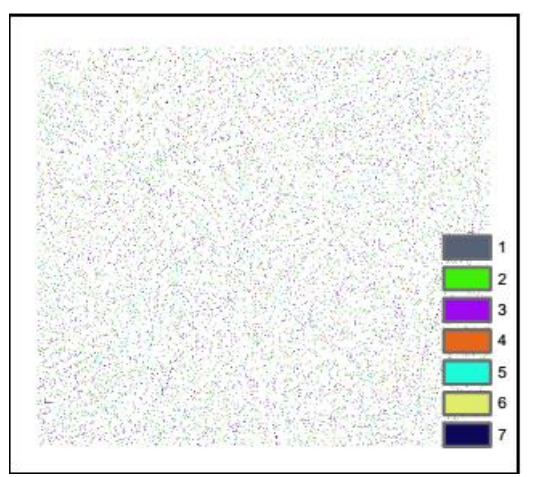

Fig. 6: Stream order.

The stream order of the study area obtained above is in raster form. To analyze the direction of flow, it is necessary to vectorize it.

The line feature of stream order of the study area was obtained as shown below. 


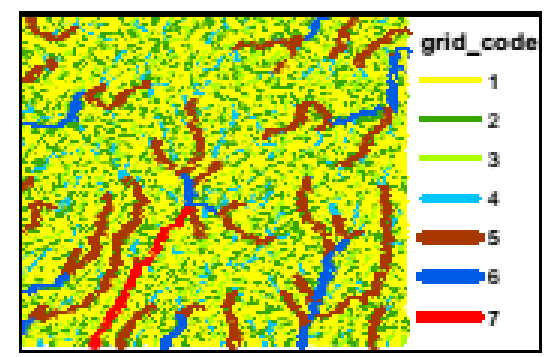

Fig. 7: Streams in vector form

\section{CONTOURING AND SITE SELECTION}

Contours are defined as the lines that connect points of equal values such as elevations. In a raster dataset, a contour line can be used to represent continuous phenomena such as elevation, temperature, precipitation, pollution, or atmospheric pressure.

Usually, contour lines are used to represent the topographic surface of the earth. Contour lines of ArcGIS tools were used to create a contour map of the study area using a $10 \mathrm{~m}$ contour interval. Figure (8) below illustrates the resultant contour map.

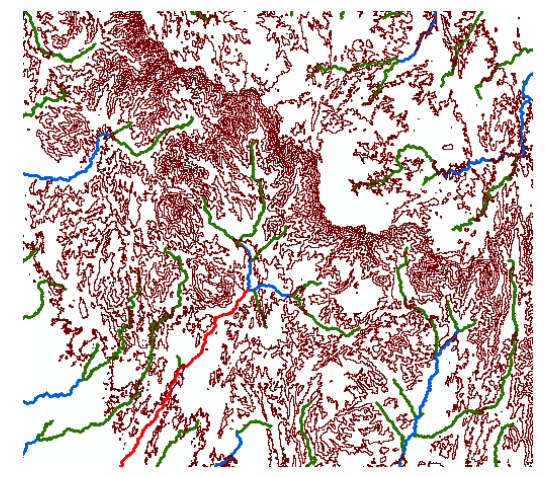

Fig. 8: contour map and streams of the study area.

After investigating the contour map of the study area, one location was proposed for constructing a dam or reservoir.

A watershed is an upslope area that contributes water flow to a common outlet as concentrated drainage.

The outlet, or pour point, is the point on the surface at which water flows out of an area. It is the lowest point along the boundary of a watershed.

After studying the contour map of the research area, a pour point was identified and selected to be $(747,214.353 \mathrm{~m}, 2,174,627.325 \mathrm{~m})$. This leads to identifying the suitable location of the proposed dam site. 
From the flow direction and the pour point, the watershed was found as shown below.

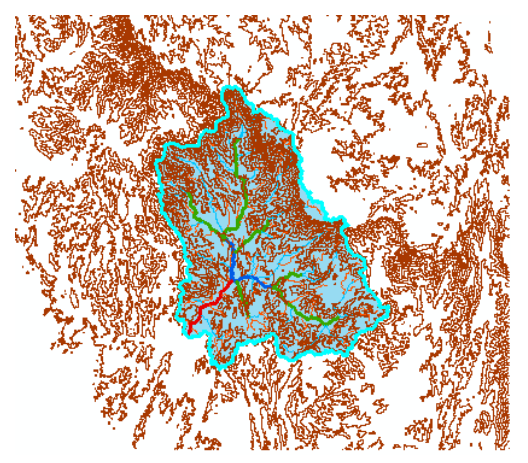

Fig. 9: The derived watershed area.

Now, to calculate the area of the watershed it is necessary to transform it from raster form to vector. The vector watershed was obtained as illustrated hereunder. The total area of the watershed was found to be about $1,006,770,000 \mathrm{~m}^{2}$.

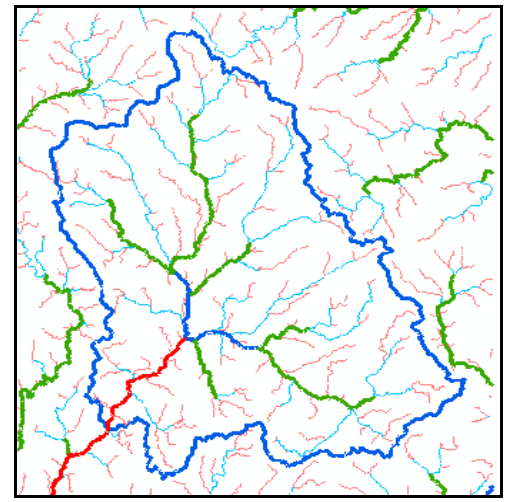

Fig. 10: Watershed in vector form.

The rainfall for the proposed location is approximately $581 \mathrm{~mm} \cdot{ }^{[4]}$ Thus, the proposed location is expected to receive rainfall estimated at $858,000,000 \mathrm{~m}^{3}$.

The watershed heights vary from $255 \mathrm{~m}$ to $2508 \mathrm{~m}$ above mean sea level. By investigating contour lines through the watershed area, three cases were studied. The first was the higher contour height that can reserve a higher height of water. Thus, the maximum expected volume. The second was the lower contour. Where the third case was a medium contour height that was in between.

The higher contour selected, was the contour at $300 \mathrm{~m}$ elevation. This contour was selected and exported as a separate layer to determine the dam lake at this height. The dam lake was 
derived as shown in figure (11) below. The area of which was calculated to be $17,271,389$ $\mathrm{m}^{2}$, with $426,050,100 \mathrm{~m}^{3}$ volume.

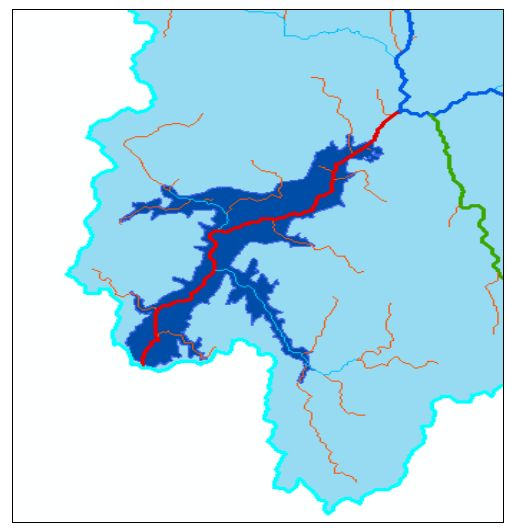

Fig. 11: Dam Lake of 300 m elevation.

Moreover, the dam length at this elevation was measured to be $625 \mathrm{~m}$ with $78 \mathrm{~m}$ height as plotted in the cross-section illustrated in figure (12).

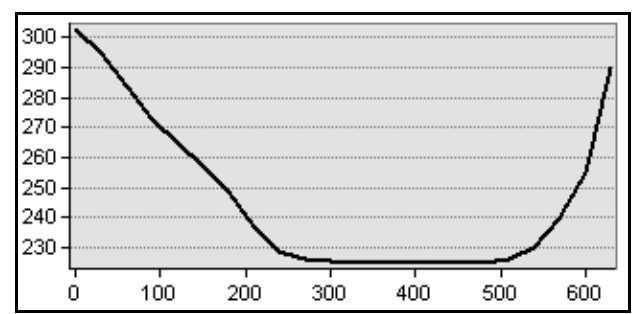

Fig. 12: Dam cross-section at $300 \mathrm{~m}$ elevation

The contour line at elevation $270 \mathrm{~m}$ was selected to be between the higher and the lower contour height. Again, this contour was selected and exported as a separate layer to determine the dam lake at this height. The dam lake at contour $270 \mathrm{~m}$ was derived. Its area was found to be $5,737,723 \mathrm{~m}^{2}$ with a volume of $101,961,900 \mathrm{~m}^{3}$.

Figure (13) below, illustrates the dam lake at an elevation of $270 \mathrm{~m}$. 


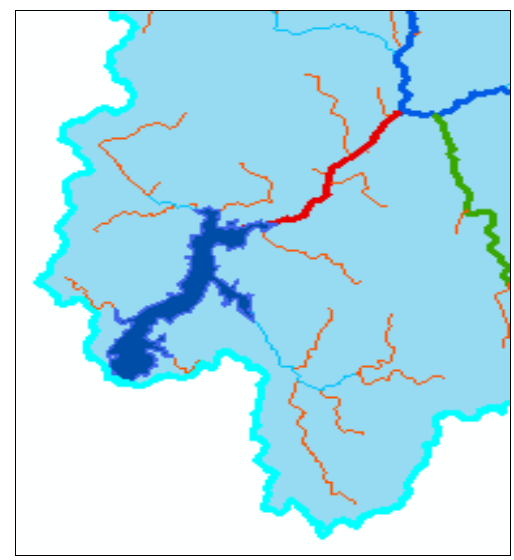

Fig. 13: Dam lake of 270 m elevation.

Again, the dam length of the lake at an elevation of $270 \mathrm{~m}$ was measured to be $454 \mathrm{~m}$ with 30 $\mathrm{m}$ height. Figure (14) is the cross-section of the proposed dam at elevation $270 \mathrm{~m}$.

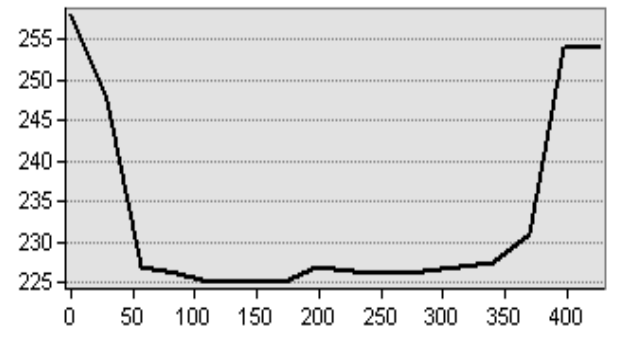

Fig. 14: Dam cross-section at 270 m elevation.

The final proposal examined, was done by selecting a minimum elevation at which a dam can be located. This elevation was determined as $240 \mathrm{~m}$. The lake created by this elevation was derived as shown in figure (15) illustrated below. The area of this dam is 1,219,042 $\mathrm{m}^{2}$ and its volume is $9,805,500 \mathrm{~m}^{3}$.

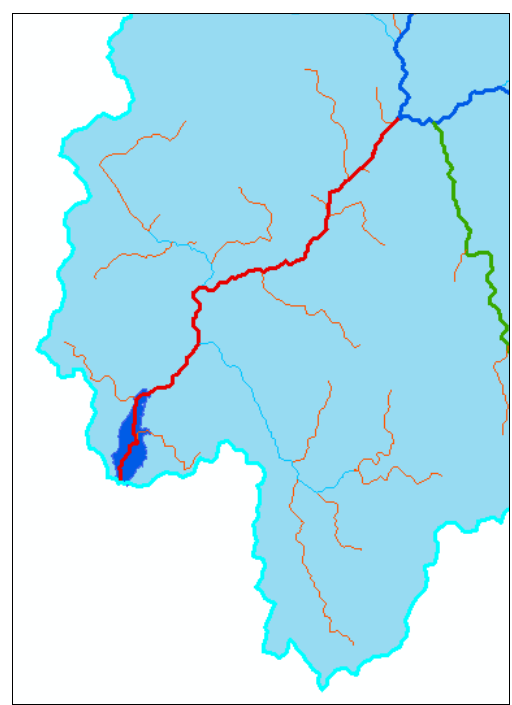

Fig. 15: Dam lake of 240 m elevation. 
The profile hereunder is the section across the dam at elevation $240 \mathrm{~m}$. Its length is $247 \mathrm{~m}$ with $5 \mathrm{~m}$ in height.

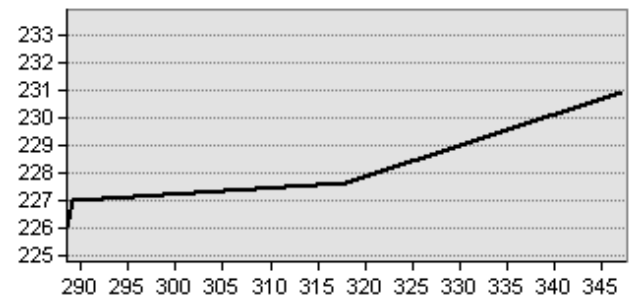

Fig. 16: Dam cross-section at 240 m elevation.

The figure below is representing the three proposed lakes merged in one diagram.

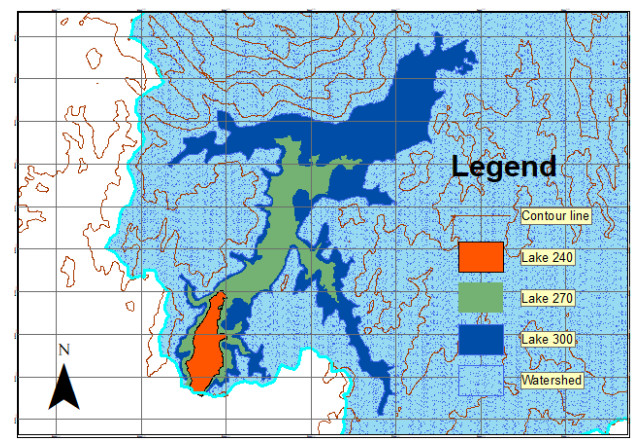

Fig. 17: Map of the three proposed lakes.

Table (1) Below, arranges the proposed dam's elevations and heights and lakes areas and volumes.

Table 1: Comparison between the proposed dams.

\begin{tabular}{|c|c|c|c|c|c|}
\hline $\begin{array}{c}\text { Proposal } \\
\text { No. }\end{array}$ & $\begin{array}{c}\text { Elevation } \\
(\mathbf{m})\end{array}$ & $\begin{array}{c}\text { Dam height } \\
(\mathbf{m})\end{array}$ & $\begin{array}{c}\text { Dam length } \\
(\mathbf{m})\end{array}$ & $\begin{array}{c}\text { Lake area } \\
\left(\mathbf{m}^{\mathbf{2}}\right)\end{array}$ & $\begin{array}{c}\text { Lake volume } \\
\left(\mathbf{m}^{\mathbf{3}}\right)\end{array}$ \\
\hline 1 & 300 & 78 & 625 & $17,271,389$ & $426,050,100$ \\
\hline 2 & 270 & 30 & 454 & $5,737,723$ & $101,961,900$ \\
\hline 3 & 240 & 5 & 247 & $1,219,042$ & $9,805,500$ \\
\hline
\end{tabular}

\section{CONCLUSION AND RECOMMENDATION}

Rainwater harvesting could be a practical solution to water shortage and water security.

This research work aims to apply GIS in dam or reservoir site locating and mapping according to topographic elevation analysis of a particular area. Elevation information is the main source of raw data here. DEM was used to reflect a clear topographic image of the study area. Arc GIS 10.8 was used to process and derive the required data. From the collected data and analysis carried out it can be concluded with the following points 
- One site was identified and selected to propose a dam or reservoir. This site was located in Almikhwah province. Its pour point was selected to be $(747,214.353 \mathrm{~m}, 2,174,627.325$ $\mathrm{m})$.

- Suitable dam elevations were proposed to vary from $300 \mathrm{~m}$ to $240 \mathrm{~m}$ above mean sea level.

- The minimum dam length could be $247 \mathrm{~m}$ with $5 \mathrm{~m}$ height and about 9,8 million cubic meter storage capacity.

- 426 million cubic meter volumes can be stored with $625 \mathrm{~m}$ dam length and $78 \mathrm{~m}$ height.

- DEM analysis using special analysis GIS tools is helpful in dam site selection.

- Since this study is limited to a DEM analysis, further works can be carried out to study the same location taking into consideration other factors that govern dam site selection such as geology and earthquake zone.

\section{REFERENCES}

1. Arsalan Ahmed Othman and others, GIS-Based Modeling for Selection of Dam Sites in the Kurdistan Region, Iraq, International Journal of Geo-Information, 2020; 9(4).

2. Eiman Eisa Ahmed Elhaj, and Nagi Zomrawi Mohammed Assessment of Pharmaceutical Service Distribution Using GIS (A Case Study of Khartoum Locality), International Research Journal of Engineering and Technology (IRJET), 2020; 7(6).

3. Erica DeNicola and others, Climate Change and Water Scarcity: The Case of Saudi Arabia, Annals of Global Health, 2015; 81(3).

4. Erica DeNicola, Omar S. Aburizaiza, Azhar Siddique, Haider Khwaja, David O. Carpenter, Climate Change and Water Scarcity: The Case of Saudi Arabia, Annals of Global, Health, 2015; 81(3).

5. Esri, Arc GIS 10.8 manual, 2019.

6. Muhammad Ateeq Qureshi Dam / Reservoir Sites Selection Using Remote Sensing \& GIS Techniques, 2015.

7. Rami Al-Ruzouq and others, Dam Site Suitability Mapping and Analysis Using an Integrated GIS and Machine Learning Approach, Water, 2019; 11: 1880.

8. https://en.wikipedia.org/wiki/Al-Bahah_Province.

9. https://www.engineeringarticles.org.

10. https://www.mewa.gov.sa/en/Ministry/AboutMinistry/Pages/MinistryVision.aspx.

11. https://www.stats.gov.sa. 